\title{
TWO HYMNS OF DORING RE
}

\section{Zakariya ABDEL-MAGIUD*}

\begin{abstract}
: ${ }^{1}$
A publication of a Late Period painted wooden stela of T3-jrj, daughter of the priest of Amun Jmn-htp. The stela is exhibited in the Cairo Museum and bears the temporary registration numbers (TN 27/1/25/16) and (SR. 9914). The stela was found at El-Qurna and dated back to the XXVI Dynasty. It measures $45.5 \mathrm{~cm}$ height and $0.23 \mathrm{~cm}$ width. The surface is generally well preserved, except in certain damaged areas. Traces of color are still visible. The stela records two hymns of adoring Re when he rises in the eastern horizon of the sky and when he sets in the west.
\end{abstract}

\section{Introduction.}

The stela of $T_{3}-\mathrm{jrj}^{2}$ is one of a large number of very interesting Late Period wooden funerary stelae among the objects in the magnificent collection of antiquities in the Cairo Museum. ${ }^{3}$ It is noteworthy that the owners of these stelae are mostly persons attached to

\footnotetext{
${ }_{1}^{*}$ Institute of Africa Studies, Cairo University (Egypt)

${ }^{1}$ I would like to express my deep gratitude to Prof. Dr. A. Zayed for providing me with the photo of this stela.

${ }^{2}$ Some scholars have referred to this stela, but it has never been fully published, see: K. Piehl, Inscr. Hiero. III, pl. LXXXV (X); J. Lieblein, Wb, no. 2281; $P M$ I2, 802; De Meulenaere, H., „Un prêtre d'Akhmim à Abydos“, in: CdE 44,, no. 88, 1969, 268; P. Munro, Die spätägyptischen Totenstelen, ÄF 25, Glückstadt 1973, 202; M. Bierbier, Late New Kingdom, 92ff; G. Vittmann, Zu den thebanischen Totenstelen der 25. und 26. Dynastie (Korrekturen und Ergänzungen zu P. Munro, Die spätägyptischen Totenstelen [ÄgFo. 25] 187-228), in: Or 47, 1978, 4; G. Vittmann, Priester und Beamte im Theben der Spätzeit. Genealogische und prosopographische Untersuchungen zum thebanischen Priester- und Beamtentum der 25. und 26. Dynastie, Wien, 1978, 25ff; H. Brugsch in: Z̈̈S 6 (1868), 124

${ }^{3}$ Some publications geared specifically to the study of Late Period funerary stelae, see: S. Bosticco, Museo Archeologico di Firenze. Le stele Egiziane di Epoca Tarda. Istituto Poligrafico dello Stato, Rome 1972; P. Munro, Die spätägyptischen Totenstelen, ÄF 25, Glückstadt 1973; H. Stewart, Egyptian Stelae Reliefs and Paintings from the Petrie Collection III: The Late Period, Warminster 1983. A large number of Late Period funerary stelae have been published in detail, see: A. Zayed, "Painted Wooden Stelae in the Cairo Museum", in: RdE 20, 1968, 149-170; A. David, Tomb Groups from the End of the New Kingdom to the Beginning of the Saite Period. Ph. D. Dissertation, University of Birmingham, Birmingham 1987; A. Abdalla, "Wooden Stela from the Late Period on the Cairo Museum", in: VA 4, 1988, 5-16; H. El-Leathy, "Painted Wooden Stelae from Thebes. From the $21^{\text {st }}$ to the $26^{\text {th }}$ Dynasties", in: OLA 150.1, 2007, 585-594. Four doctoral dissertations have dealt with Late Period wooden funerary stelae, see: J. Taylor, The Development of the Theban Coffins During the Third Intermediate Period: A Typological Study. Vol. I-II. Ph.D. Dissertation, University of Birmingham, Birmingham 1985, D. Aston, Tomb Groups from the End of the New Kingdom to the Beginning of the Saite Period, Ph.D. Dissertation, University of Birmingham, Birmingham 1987; S. Onstine, The Role of the Chanters (̌̌myt) in Ancient Egypt. Ph. D. Dissertation,
} 
the cults of the gods Month and Amun. The stelae vary in size from a few centimeters to nearly one meter. They vary also in workmanship, some being very carefully inscribed and artistically decorated, while others are quite opposite. With some exceptions, usually the larger stelae are the best in this respect.

One may wondered why wood should have been used as a material for these stelae, and the first idea that comes to mind is reason of economy. But a close study of the material in hand seems to dispute that reason. For one thing, the better-class wooden stelae cannot have been cheap. They have evidently been decorated by fist-class artists in that type of work, and some of them are even embellished with gold. Moreover, many of them belonged to persons of good social standing. Perhaps the portability of wood against the heaviness of stone determined the use of the former material. A very interesting point about these stelae is the evidence they afford for the religious views of the Period. The most striking is the identification of the forms of Horakhty with Soker-Osiris. ${ }^{4}$ It is noteworthy that all stelae seem to originate from Thebes and its neighborhood, namely from the Ramesseum, Deir el-Bahari, El-Qurnah, and Medinet Habu. Our first stela was found at El-Qurnah in 1862, while the second was found in $1859 .^{5}$

\section{REPRESENTATION:}

The stela (fig. 1, pl.1) is divided into three registers; the upper one, which is surmounted by a frieze of stars representing the sky, is occupied by a winged sun disk with two pendants Uraei. Below this, is a line of hieroglyphs, repeated twice and reads:

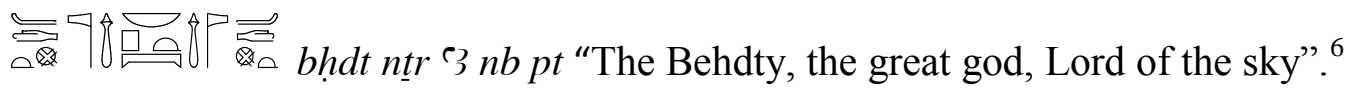

University of Toronto, Toronto 2001; L. Swart, A Stylistic Comparison of Selected Visual Representation on Egyptian Funerary Papyri of the $21^{\text {st }}$ Dynasty and Wooden Funerary Stelae of the $22^{\text {nd }}$ Dynasty (c. 1069-715 B.C.E.). Ph.D. Dissertation, University of Stellenbosch, 2004.

${ }^{4}$ A. Zayed, "Painted Wooden Stelae in the Cairo Museum", in: RdE 20, 1968, 149-150.

${ }^{5}$ It has been suggested that the Late Period wooden stelae were a Theban phenomenon, H. Saleh, Investigating Ethnic and Gender Identities as Expressed on Wooden Funerary Stelae from the Libyan Period (c. 1069-715 B.C.E.) in Egypt, Ph. D. Dissertation, University of California, Berkeley 2006, 3; although some stelae may have come from Abydos, A. Leahy, "Two Late Period Stelae in the Fitzwilliam Museum", in: $S A K$ 8, 1980, 169-180.

${ }^{6}$ The overall purpose of the lunette decoration is to include symbols that might aid the deceased as Osiris tobecome Re, who crosses the heavenly skies (A. Niwiński, Iconography of the Twenty-First Dynasty: Its Main Features, Levels of Attestation, the Media and their diffusion, $O B O$ 175, 2000, 35; Solar imagery dominates the decoration of the lunette with a combination of a sky-sign and a winged sun-disk (E. Russmann, Eternal Egypt. Master works of Ancient Art from the British Museum. University of California Press, Berkeley, 2001, 221). The ubiquitous blue sky-sign arches slightly to fit the curvature of the roundtop. Similarly, the winged sun-disk curves a bit to fit the lunette. The sun-disk is red, and it is surrounded with multi-coloured plumage. The wings can be either extremely detailed or schematic. Two uraei were typically added to the sun-disk. The term $b h d t$, which means "the one from Edfu" is the most common epithet for the winged sun-disk, and it is inscribed directly below the winged sun-disk (R. Hölzl, "Round- 
At the upper part of the second register, which is completely framed by borders of colored rectangles, is a frieze of $\underline{h} k r$-ornaments framed by a block border. 7 Below this are two main scenes. The scene to the right shows the deceased lady stands facing left, and wears a long, loose-fitting robe. She raises both arms in adoration towards Atum, who stands in front of her, wears the double crown, a corselet, and a short kilt and tunic. The god carries the $w 3 s^{-}$- scepter and the ' $n h$-sign. Between the Lady and the god is a libation stand with a jar and a very large lotus flower. A above the god Atum are two columns of text reads from right to left: $\square \square$ 过

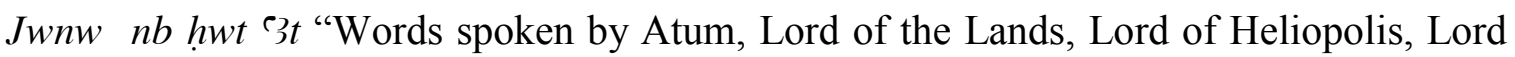
of the temple. Above the lady are three other columns of inscription reads from left to right: : बी spoken by T3-jr, Mistress of the house, daughter of Jmn-htp".

The scene to the left is similar to the above mentioned, but the god Rahorakhty, who is replaced here by Atum, is shown as a hawk-headed man, crowned with a large solar disk. Above the god is written: spoken by Rehorakhty, the great god, Lord of the sky". Above the women is written:

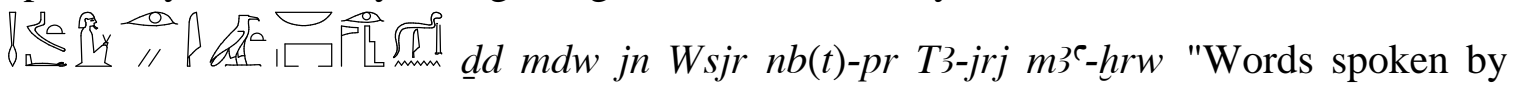
Osiris, Mistress of the house, T3-jrj, justified".

\section{TEXT.}

The third register is occupied by the main texts of the stela, recording two hymns of adoring $R e$. Each consists of nine horizontal lines of inscriptions, divided from each other by a vertical black line. The left -hand hymn is addressed to the sun-god at his rising and reads:

Topped Stelae from the Middle Kingdom to the Late Period. Some Remarks on the Decoration of the Lunettes", in: Sesto Congresso Internazionale di Egittologia: Atti I, Turin 1992: 288). The winged sundisk, which personifies the king, became the most common decorative element in the lunette of funerary stela from the Late Period until the Roman Period (Hölzl 2001, 287). The wings associate the king with Hours, and the uraei express the duality of Upper and Lower Egypt. It is a symbol for protection and defence, see: H. Saleh, Investigating Ethnic and Gender Identities as Expressed on Wooden Funerary Stelae from the Libyan Period (c. 1069-715 B.C.E.) in Egypt, Ph. D. Dissertation, University of California, Berkeley 2006, 51.

${ }^{7}$ Border decorations frame the main scene, appearing on the right-most and left-most sides of the central register. For the most part, decorative border elements hold up or support the sky-sign in the lunette (R. Hölzl, in: Sesto Congresso Internazionale di Egittologia, 286). Aston has classified the Third Intermediate into eight groups based largely on the presence or absence of particular border decorative patterns, see: D.Aston, Tomb Groups from the End of the New Kingdom to the Beginning of the Saite Period, 566ff. 


$$
\begin{aligned}
& \text { * }
\end{aligned}
$$

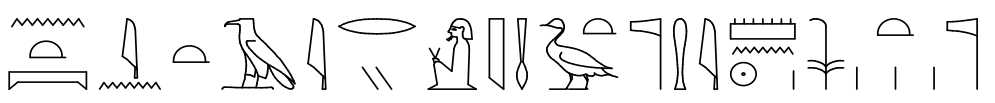

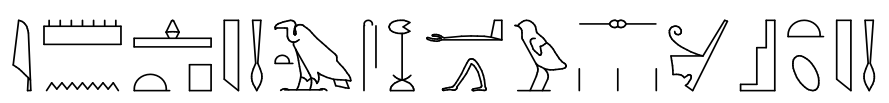

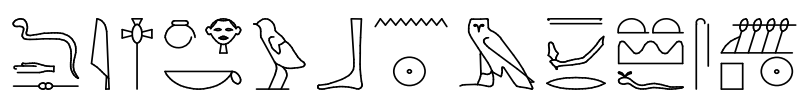

$$
\begin{aligned}
& \therefore \text { D. }
\end{aligned}
$$

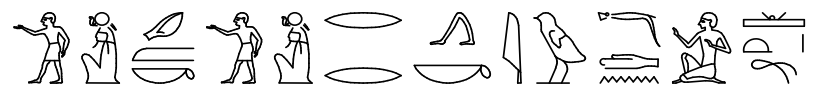

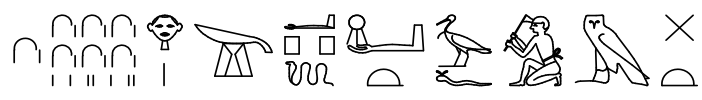

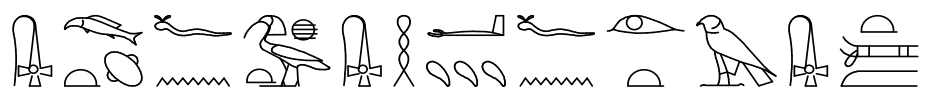

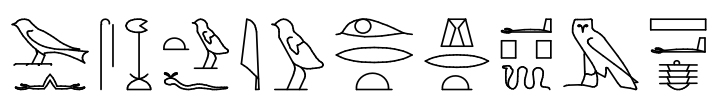




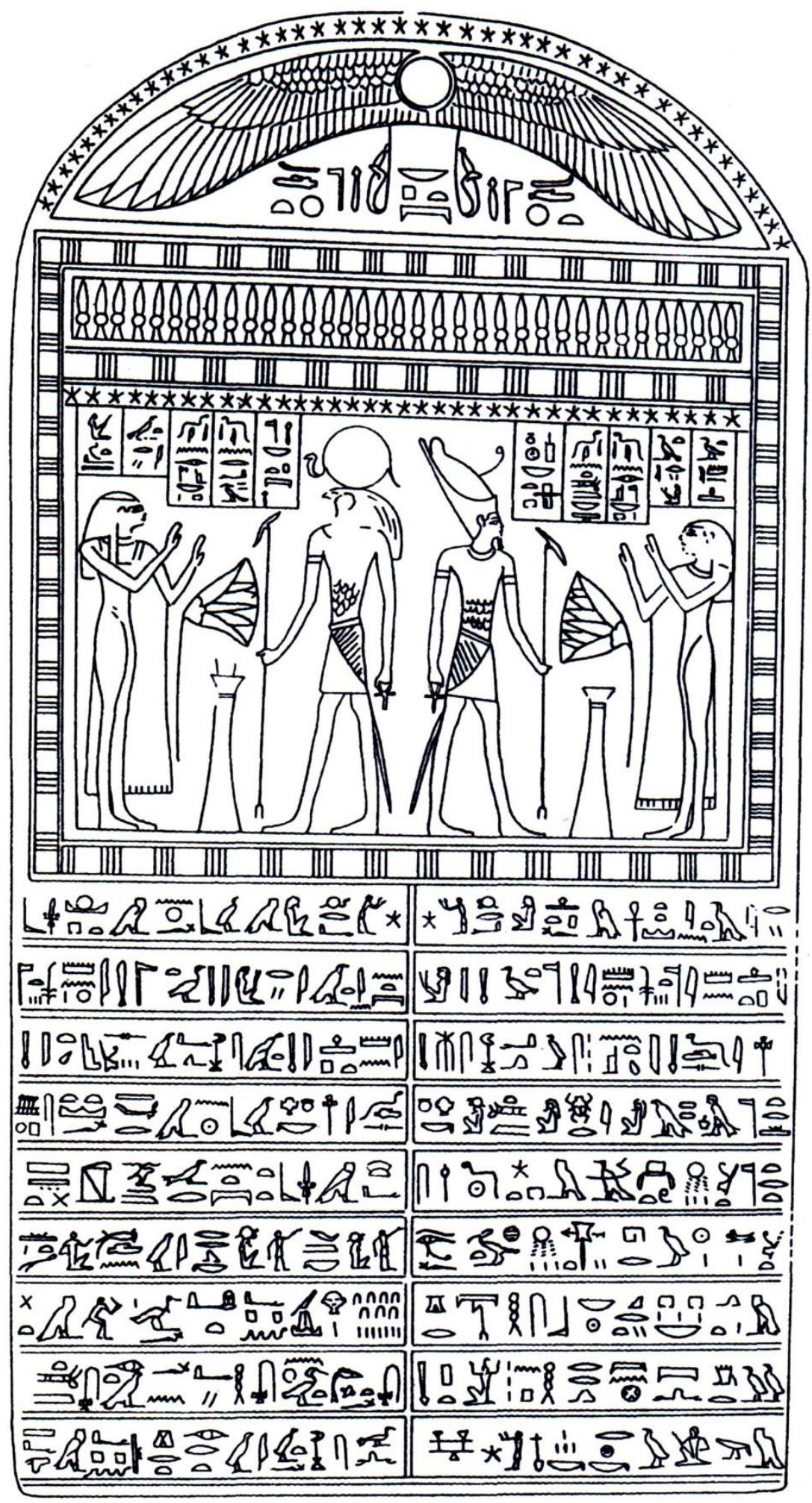

(Fig. 1) Stela of T3-jrj (Cairo Museum TN 27/1/25/16) 
$\mathrm{T} \quad \underline{d} w^{3} R^{e} m-w b n=f m$ 3ht j3btt $n t$ $p t$

$\mathrm{P} \quad$ jn T3-jrj ${ }^{(\mathrm{a})} m 3^{\mathrm{e}}-h \mathrm{hrw}$ z3t ḥm-ntrr Jmn-R $\quad$ njswt-ntrr Jmn-ḥtp $m 3^{\mathrm{C}}-h r w \quad m w t=s \quad h 3^{\mathrm{C}}=s-n-J s t^{(\mathrm{b})}$ $m 3^{e}-h r w d d=s$

$\mathrm{H} \quad j n \underline{d} h r=k$ wbn $m t 3 \underline{d} s r t=f s \check{p} p$ $h^{\ulcorner} \cdot w m$ j3btt $n t p t^{(\mathrm{c})}$ wr sfjt $m$ $k 3 r s_{t} 3^{(\mathrm{d})}$

$j R^{\ulcorner} s \underline{d} m=k j R^{\ulcorner} p \underline{h} r=k$

$j w \quad \check{s} d . n=j \quad m \underline{d} 3 t 77^{(\mathrm{e})} h r \quad n m t$ epp $r^{\mathrm{c}}-n b^{(\mathrm{f})}$

dj.tw $\quad b 3=f \quad[n] \quad h f t j \quad m \quad s \underline{d} t^{(\mathrm{g})}$ $\underline{h} 3 t=f n 3 h t h^{\top} w=f^{(\mathrm{h})} n$ jrt $\mathrm{Hr}$ $t m w^{(i)} n s h 3 . t w=f$

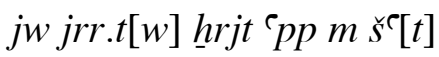

$\mathrm{T}$ Adoring $\mathrm{Re}$ when he rises in the eastern horizon of the sky.

$\mathrm{P}$ by T3-jrj, justified, the daughter of the priest of Amun, Lord of the Gods, Jmn-htp, justified, whose mother is $h 3^{\top} w s-n-J s . t$, justified, she says:

$\mathrm{H}$ Hail to you, who rises from his sacred domain, the daylight appears in the east of the heaven, the great of esteem in the secret shrine.

Oh Re, may you hear; Oh Re, may you circle about.

[for] I have read the 77 rolls concerning the place of slaughter of Apophis every day.

His soul is given to the enemy with the fire, his corpse to the flame, his flesh $<$ body $>$ to the eye of Hours, so that he ceases to exit and is not to remembered.

What is due Apophis is <regularly> accomplished in the [daily] conflict.

The hymn on the right-hand side adoring Re when he sets in the west and reads as follows:

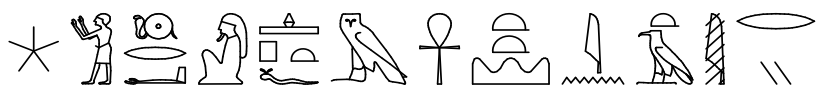




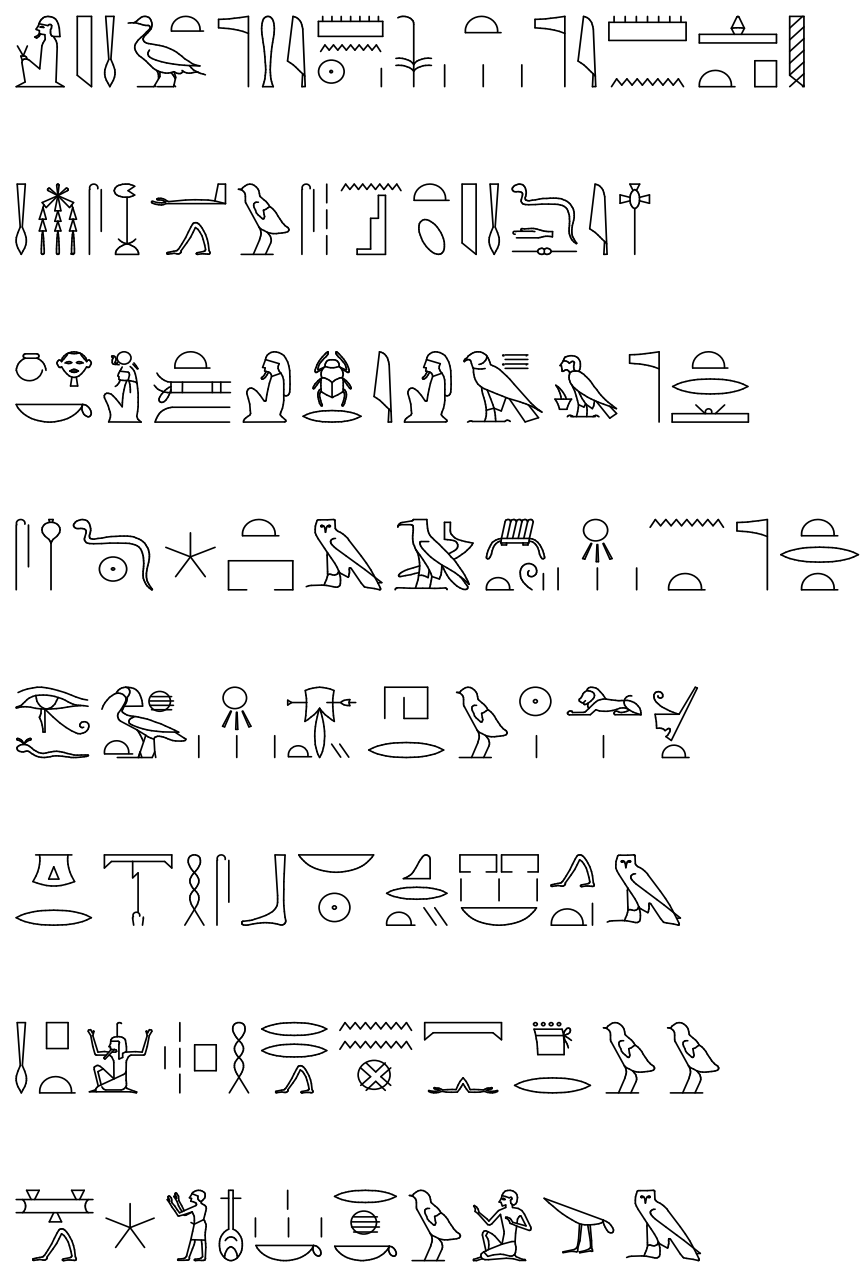

T Adoring Re when he sets in the West.

$\mathrm{P} \quad$ jn T3-jrj m3e-hrw z3t hmm-ntr Jmn-Re

$P$ by \&A-jrj, justified, the daughter of njswt -ntr Jmn-htp m3゙-ḩrw msj h] ${ }^{\top} w s-n-J s t m 3^{\top}-h r w \underline{d} d=s$ the priest of Amun-Re, Lord of the Gods, Jmn-htp, justified, being the daughter of $h 3^{\Upsilon} w s-n-J s t$, justified, she says:

$\mathrm{H} \quad j n \underline{d}-h r=k R^{e}-J t m H$ Hprj $H r-3 h t j$

H Hail to you, Re-Atum, Khepri Horakhty!

The divine soul, who illumines the b3 ntrj sḥ $\underline{d} d w 3 t m$ m3wt nt $n t r t=f j 3 h t$

stj $[m]$ hrw nb nt grh sḥb qrtj $n b$ nmtt $m$ hpt hh ph prrr Nnw[t] $n \underline{d r w}$ netherworld with the rays of his bright divine eyes,

who shines [by] day, lord of night, making festive, the twin caverns, who strides according to his will in a circuit of millions [of leagues], who courses the nether sky without limit. 
$d w 3[=j]$ nfrw $=k$ rhk $k$.wj š̌m $[=k]$
Praise your beauty, for I know [your] image.

\section{COMMENTARY.}

(a) The owner of this stela is a member of the $B s-n-M w t$ family. This family is the most complex and confusing of the many official families that are known to have flourished at the time of the Dynasty XXII8. The lady T3-jrj lived probably in the Dynasty XXVI,9 and to her can be attributed the sarcophagus CG 473510 and probably CG 41011.11

(b) For the reading of this name, see: $P N, 262: 19$.

(c) A. Abdalla (VA 4, 1988, 5-16) translated šsp hூ.w m j3btt nt pt "who receives the crown in the east of the heaven", but $s \check{s} p$ or $s \check{s} s p$ means here "daylight" and $h^{\complement} \cdot w$ is an Old-Perfective means "appear" and not crown, thus the sentence should be translated "the daylight appears in the east of the heaven".

(d) Some other parallel stelae records variants as: $\underline{h} n m R^{\top} m \mathrm{k} 3 r \mathrm{~s} t 3$ "enter, Re into the secret shrine" or hnm $m \mathrm{k} 3 r \mathrm{r} s \mathrm{t}$ "enter into the secret shrine", see, T. G., Allen, Some Egyptian Hymns, in: JNES 8, 1949, 352 (f).

(e) The number of rolls is quite different, some other parallels record 69, 70 or even 73. The daily slaughter of Apophis, the evil serpent deity of cloud and storm, is a common theme in the Egyptian literature; see, T. G., Allen, in: JNES 8, 1949, 352 (h).

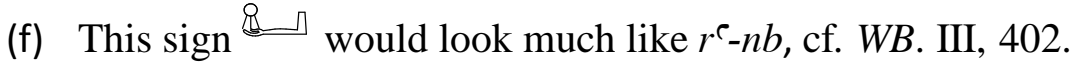

(g) $\underline{d j} . t w b 3=f n s \underline{d} t$ "His soul is given to the fire" is recorded also on other parallels, see, T. G., Allen, in: JNES 8, 1949, 352 (k).

(h) $h k 3=f$ "his magic" instead of $h^{\complement} w=f$ "his body" is also recorded on other parallels, see, T. G., Allen, in: JNES 8, 1949, 352 (k).

(i) Parallels recorded tm.tw and tmwt, each probably meant for tmtj, which would then apply to the eye of Hours instead of to Apophis and would need a different determinative and meaning, see, T. G., Allen, in: JNES 8, 1949, 352 (k).

(j) T. G., Allen (JNES 8, 1949, 353, 355) translated "nht "the region of life" as "it is the west, where interments were made. It could also be jmntt, since $f$ instead of ${ }^{\circledR}$ is a mistake. For ' $n h t$ "west". Cf. WB. I, 205:16.

\footnotetext{
${ }^{8}$ For the complete genealogy of the Bs- $n-M w t$ family, see: M. Bierbrier, The Late New Kingdom in Egypt, 92ff, cf. A. Baillet, "Une famille sacerdotale contemporaine des XXIIe-XXVIe dynasties (850-600 avant Jésus-Christ)”, in: RT 18, 1896, 187-196; G. Wittmann, Priester und Beamte, 34.

${ }^{9}$ Cf. M. Bierbrier, The Late New Kingdom in Egypt, 93.

${ }^{10}{ }^{P M \mathrm{I}^{2}}$, 824; Liebleiein, Dict. Supp., 360 (No. 1100).

${ }^{11} P M \mathrm{I}^{2}, 843$; A. Moret, Sarcophages (CG 41001-41041), 139-150; Contrary to H. De Meulenaere, $C d E ́$ 44, 1969, 268, no. 4735; G. Vittmann, $\operatorname{Or} N s$ 47, 1978, 4, no. 202, refused the attributing of this coffin to the owner of our stela.
} 


\section{CONCLUSION.}

There are a number of Late Period wooden funerary stelae from the same collection in the Cairo Museum recorded the also the same hymn of adoring Re when he sets in the west, and when he rises in the eastern horizon of the sky:

1. Stela of N3.w-mnht-Jmn, the daughter of the priest of Shu and Tefnut, the priest of Wepwawet, $B s-n-M w t$ (Thebes. Cairo Museum. S.R. 9418). ${ }^{12}$

2. Stela of $W n-n f r$, the priest of Montu (Thebes. Cairo Museum. S.R. 9419). ${ }^{13}$

3. Stela of Jrt-Hrrw- $d d[n]=f$ (Paris, Musée Guimet C47). ${ }^{14}$

4. Stela of ${ }^{\top} n h=f[-n] H n z w$ (London BM 22914). ${ }^{15}$

5. Stela of Rwrw (Abydos D11/Chicago OIM 6898). ${ }^{16}$

6. Stela of $T(3)-d j-J m n-n b-N s t$ (Copenhagen A.A.D.3). ${ }^{17}$

Our parallels are also stelae of wood except one of limestone. They seem to be of a single basic type, rounded at top, where a winged sun-disk hovers. Then come balanced scenes of worship of Re or Rahorakhty at one side, and of Atum at the other. Below this are the paired hymns, each reading outward from the center. Some sources is identical with our stela in placing Atum and a hymn of the settting sun at our right, others place these at our left. It is interesting to notice that N3.w-mnht-Jmn and Wn-nfr (owners of stelae nos. 1-2) are also members of $B s-n-M w t$ family. This could explain the similarity of the artistic style of the three stelae, which made their texts seem to be copies and are made by the same hand. The arrangement of the transliteration and translation suggested that this hymns is truly poetic in both form and imagery. Our two hymns are derived from chapter 15 of $\mathrm{BD}$, which is divided by Lepsius into individual hymns, called (15 c). Naville added other hymn groups, which he called (15A I-IV) and (15B I-III). Allen completed the hymn groups by adding $(15 A 5,15 B 4-5)$ and $(15 h)$. According to his classification our hymns belong to his group $(15 A 5,15 B 4)$, addressed to the rising and the setting sun respectively.

The sun god is often addressed in solar hymns simply as Re "sun", but he also appears in more specific identifies associated with one or more of the phases of the daily solar cycle: in the morning as Khepri "Evolving One" or Horakhty "Hours of Akhet, the space between the netherworld and the visible horizon"; during the day as Re, Hours "Far One", or Horakhty; and at sunset as Atum "He who Finishes". The chice of name also reflects the various roles of the sun god as creator "Atum", source of light and life "Re", and ruler of the universe "Hours". Since the same functions are associated with the creator and supreme deity, Amun, this od also appears as the object of solar hymns, usually in the

\footnotetext{
12 This stela has been published by A. Zayed, in: RdE 20, 1968, 164-165, Pl. 14 B.

${ }^{13}$ This stela has been published by A. Abdalla, in $V A$ 4, 1988, 7,12, fig. 5.

${ }^{14}$ T.G. Allen, in: JNES 8, 1949, 350-351.

${ }^{15}$ G. Legran, "Textes recueillis dans quelques collections particulières", in: $R T$ 14, 1893, $58 f$.

${ }^{16}$ T.G. Allen, in: JNES 8, 1949, 350-351, pl. XXV.

${ }^{17}$ K. Piehl, Inscr. Hiero. I, pl. XC (A).
} 
form of Amun-Re or more elaborate combinations such as Amun-Re-Harakhty.Hymns addressed to the sun god typically have a bipartite structure, consisting of a title followed by the hymn itself. The title is normally in the infinitival form $d w 3 \mathrm{X}$ jn $\mathrm{Y}$, "worshiping $\mathrm{X}$ by $\mathrm{Y}^{\prime}$, where $\mathrm{X}$ and $\mathrm{Y}$ are the names of the sun god and the worshiper, respectively. The body of the hymn, addressed to the god, is often introduced by the words $j n \underline{d} h r=k$ "Hail to you".

Solar hymns typically are associated with a particular part of the sun's daily cycle, specified in the hymn's title with a phrase such as $m w b n=f$ "in his rising" or $m$ htp $=f$ "in his setting" added after the god's name. The hymn itself, however, often makes reference to the three parts of the solar day: sunrise, daytime, and sunset. Each phase, in turn, is associated with the process of life itself: the sunrise with creation and birth; daytime with triumph over the forces inimical to life; and sunset with death and the promise of new life. The most important of these is sunrise, the beginning of the Egyptian day. The use of solar hymns in that setting is reflected in the lexical root shared by the verb $d w 3$ "worship" and the noun $d w 3 w$ "morning", and in the posture of Egyptian worship -hands raised with the palms facing outwards- which may derive from the gesture, often depicted in Egyptian art, of baboons facing the rising sun.Solar hymns are first attested in their typical form in the New Kingdom, but the genre is prefigured by a short "Morning Litany" that appears in the Pyramid Text of the Old Kingdom. The earliest attested solar hymns belong to a cycle intended for recitation at each hour of the day. This hourly ritual first appears in the temple of Hatshepsut at Deir El-bahri, although its language is suggestive of a Middle Kingdom. Solar hymns are the best-represented of all Egyptian hymns. They appear on the walls of the temple, on stelae and stelophorous statues, in liturgical papyri and those of literary character such as the Cairo "Hymn to Amun-Re" and on ostraca. Solar hymns are also frequent in funerary contexts - on pyramidia from private tombs, in the doorways of tombs, among netherworld texts such as the Book of Day and Night, and in the Book of Going Forth by Day (spell 15) -where they allow the deceased to participate in the daily solar cycle. ${ }^{18}$

\footnotetext{
${ }^{18}$ J. Allen, "Solar Hymns:, in: The Oxford Encyclopedia of Ancient Egypt, vol. II, Cairo, 2001, 146-148. Solar Hymns has been widely discussed by many scholar, J. Assmann, Liturgische an den Sonnengott, MÄS 19, 1969; Produced a study and translation of liturgical solar hymns; J. Assmann, Ägyptische Hymnen und Gebete, München, 1975, translated of more than 100 ancient Egyptian solar hymns, with an extensive introduction; J. Assmann, Sonnenhymnen in thebanischen Gräbern. Theben I, Mainz am Rhein, 1983, studied and translated solar hymns found in tombs. A. Scharff, Ägyptische Sonnenlieder, Berlin, 1922, produced an early study of solar hymns; H. Stewart, "Traditional Egyptian Sun Hymns of the New Kingdom", in: BALond 6, 1967, 29-74, studied the core themes and phrases common to many solar hymns; J. Zandee, "Prayers to the Sun-God from Theban Tombs", in: Jaarbericht van het vooraziatisch-Egyptische Genootschup 16, 1959-1962, 48-71) studied and translated the solar hymns in the doorways of several major tombs.
} 


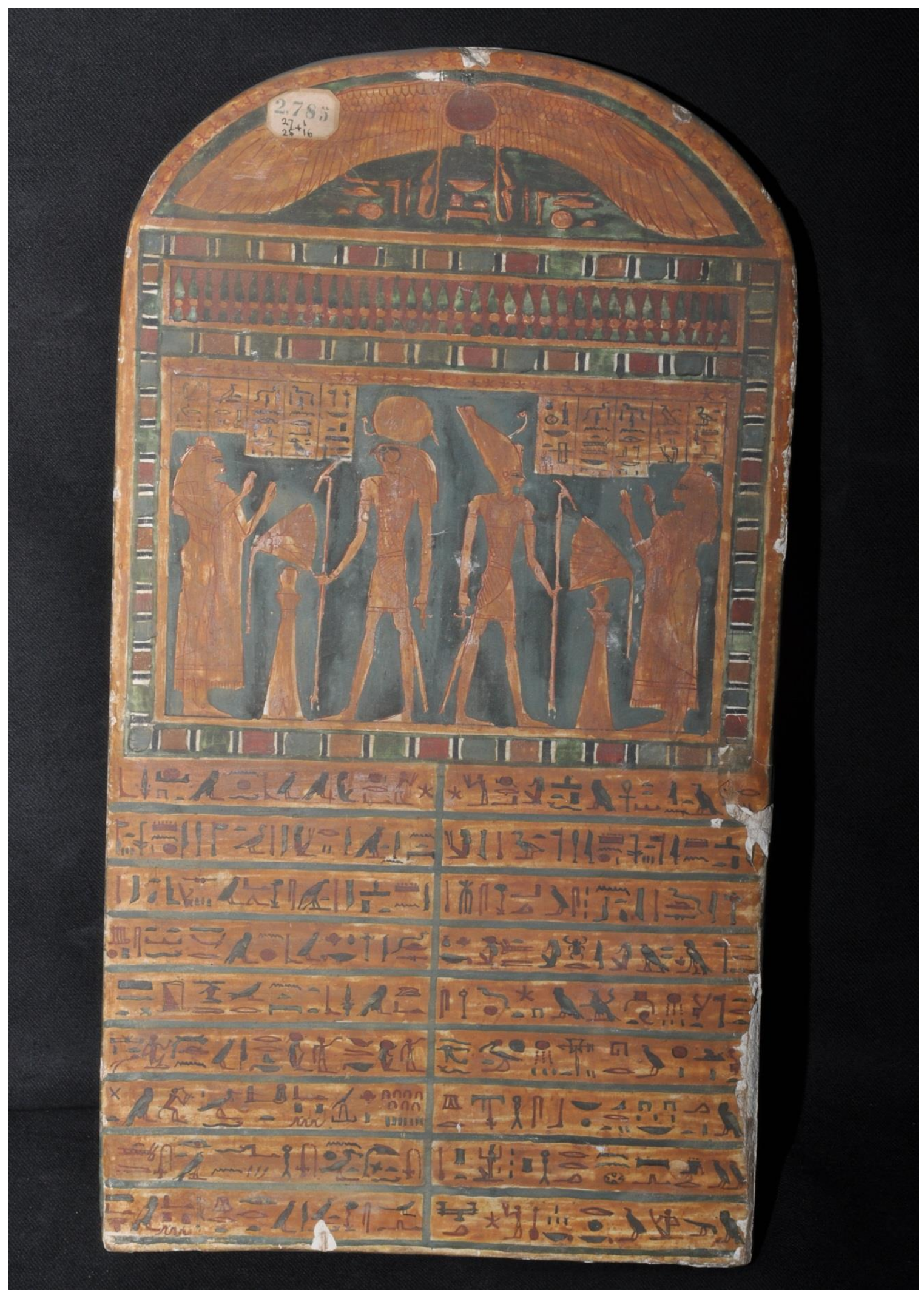

Pl. 1: Stela of T3-jrj (Cairo Museum TN 27/1/25/16) 